\title{
The Analysis of Classroom Activities Pursuant \\ to Effective Technique Teaching English in Integrated Vocational Schools
}

\author{
Heli Agustin, Leff Noviyenti, Henny Septia Utami \\ Institut Agama Islam Neger (IAIN) Curup, Indonesia \\ heliagustin01081996@gmail.com
}

\begin{abstract}
The objective of this research are to describe classroom activities pursuant to effective techniques teaching English in integrated vocational schools, and to investigate classroom activities pursuant to effective techniques teaching English in integrated vocational schools at Islamic integrated Rabbi Radhiyyahand vocational high school Islamic integrated KhoiruUmmah in Curup RejangLebong. The design of this research is descriptive qualitative. The subject of this research were two teachers who teach English in Islamic integrated vocational schools. In collecting the date, the researcher used the following techniques: checklist observation and interview. There are some instruments which the researcher used forcollecting the data, consist of: notes and interview guidance. The notes was used to find the techniques the teachers used, the classroom activities the teacher used, and identify the classroom activities that pursuant to techniques suit the elements of effective teaching, and the interview guidelines was used to find the technique the teachers used based on the theory of elements of effective teaching. In analyzing the data,the steps were data managing, description, and interpreting. Theresult from notes and interview showed that the techniques and classroom activities the teacher used and all techniques and classroom activities pursuant with element of effective teaching. The elements of effective teaching consisted of academic learning time, use of positive reinforcement, cues and feedback, cooperative learning activities, classroom atmosphere, high order questioning, direct instruction, and indirect teaching.
\end{abstract}

Keywords: technique teaching, classroom activities, elements of effective teaching

\section{Introduction}

Teaching is concern with the cognitive and psychomotor aspect of children to be more acquainted more competent of critical thinking, systematic, objective, and skilled of doing something. The purpose of teaching is more easily determined than educational purpose [1] and the 
teaching has activities based on the techniques the teacher used. As the mention by Usman (1993:P.5).

"Teaching is important for learning because when someone learning something they can get knowledge and some experience."

Though, this basic definition of teaching also applies to the regular classroom setting intechnical and integrated vocational schools programme. But, in the teaching of practical skills, there are various teaching techniques available to be adopted, just as in all other fields and to all teachers: the most appropriate teaching teqhniqueto adopt in teaching technical and vocational skills should be that which can motivate the students and sustain theirinterest in the course of instruction.

The effectiveness of teaching process have impact for the students understanding in leaning process. According to Marland and states (1996: P.68)"students in Australian school describe a good teacher in the following form: help you with your work, explain well so you can understand, is friendly and easy to get on with, make lesson enjoyable,cares about you, has a sense of humor, control the class well, and knows what he or she is talking about."At the same time, there has been much debate among teachers educators concerning how teacher education can best foster effective teaching taking account of the governments views on teacher training, the teacher educators' own professional views of how training is best conducted, and the findings of research studies looking at aspect of effective teaching and the impact of training.

Integrated vocational high school, which provides individuals with the knowledge, skills and competencies and improvingtheir abilities in a variety of ways, good religion, puts forward its function and qualitative power according to country'seconomic situation. Therefore, the reason of vocational schools is labor market, and its main goal is to meetthe demands of business world and workforce for it. This aim is not against the political stance of vocationaleducation: on the contrary, a common purpose supported by public. In integrated vocational high school actually their really need English for understanding the tools of their department, because the basic of vocatioanal high school is seldom uses classroom English. That is way, we compolsory know about English language.Vocational school is one of the component of education most directly concerned with the acquisition of the knowledge and skills that required by workplace.Refer to the education system structure of Indonesia, theterm of vocational school has spitted into two meanings, in highereducation level and in secondary education level. The vocational education inhigher education levels are usually conducted at a universities or a polytechnics, whereas the vocational 
education in secondary education levels are implementedat school that known as 'Sekolah Menengah Kejuruan (SMK)' (VocationalSecondary High School).

In vocational high school Islamic integrated Rabbi Radhiyyahand vocational high school Islamic integrated Khoiru Ummah in Curup Rejang Lebong, it is found different techniques were employed when the teachers taught the students in the class. Based on my first observation, students from both schools were greatly interested when the teachers used teaching technique. It is also found in the class the teachers presented some English videos for brainstorming after that the teachers divided students in two several groups it is for make students more active in the class, on the teaching process teacher given some questions and the students directly answered the question. Sometimes, on the teaching learning process the teachers used picture as a media in learning process, so the students and the teachers got feedback.

Then, based on the second observation from the teachers they used different techniques too in teaching learning process. In vocational high school Islamic integrated KhoiruUmmah the techniques the teachers used some techniques such as a group discussion, a short written exercise, explain picture. When the teachers used creative techniques the students reaction is really good, their apply the techniques that the teachers has given. From vocational high school Islamic integrated Rabbi Radhiyyah the teachers also used different techniques in the class. The teacher used students debate technique and class games, presentation stage, practice stage, and production stage and extra. From that techniques the students directly gave more participant and make communication with their friends in learning process.

Therefore, the schools and the students got good achievement in English and another subject in both school based on the data when the researcher did pre-observation in both school. In vocational high school Islamic integrated KhoiruUmmah the score in their report is good almost completed, and then some of students follow some national competitions like a speech, write short stories in English, debate and swimming. That nationality champions related with eight techniques used by teachers. Vocational high school Islamic integrated Rabbi Radhiyyah their achievement is good, although so many activity they did. The good achievement such as the score of the students is higher average by used the creative techniques from the teachers and the students followed some competitions. It means the techniques used by teacher in the schools and class is very good achievement for the students in the class and in their life. 
The researcher is really interested to delve what techniques and what classroom activities the teachers used for the students and the effectiveness of techniques in teaching English used by the teachers in vocational high school Islamic integrated KhoiruUmmah and vocational high school Islamic integrated Rabbi Radhiyyah. Based on the reason above the researcher interested to investigate about "An Analysis of Classroom Activities pursuant to Effective Techniques Teaching English in Integrated Vocational Schools".

\section{Research Questions}

Based on the background above, the researcher questions were formulated as follows :

1. What are the techniques used by teachers in teaching English in integrated vocational schools?

2. What are the classroom activities used by teachers in the implementation of techniques teaching?

1. How the classroom activities pursuant or not with techniques based on the effective teaching theory?

\section{Objectives of the Research}

The purposes of this research are :

3. Identify teaching techniquesused by teachers in teaching practical instructions.

4. Identify the classroom activities in implementation techniques teaching in classroom.

5. Identify the classroom activities that pursuant or not with the technique teaching based on the theory of effective teaching in integrated vocational education.

\section{Definition of the Key Terms}

The following discussion would provide the description on the key terms of the research. The explanation would cover three items; effective teaching, teaching techniques, and integrated vocational school.

Teaching Technique. Based on Jerome's statement "Teaching is the supply the idea, the problems or the knowledge as sample, so that the students can understand". Brown(2001) the technique is specific activities manifested in the classroom that is consistent with a method and therefore is in harmony with an approach as well. 
Classroom activity is several activities that the students show their educations' activity used team work or individual, if the classroom does not have real some activities, so the learning process can not effectively and the students could be a passive. The purpose of classroom activities is to give students exposure to context before they complete a related performance task such as reflects students knowledge of the construct, rather than context.

Vocational school is one of secondary school with a specialty to prepare graduates to be ready to work. Integrated vocational school. Suyanto(2013) where part of school include Islamic religions in subject, lesson, or activities. Integrated vocational school medify and deveoped their curriculum to reach the min goals of the establishment of school is among: make the students be islamic personality, have smart think and intelegent faith.

Based on the theory from Anthony's "Technique is the level at which classroom procedures are described. It is implementation that which actually takes placein a classroom. It is the particulartrick, stratagem, or contrivance used to accomplish an immediate objective."Technique must be consistent with a method, and therefore in harmony with anapproach as well. Technique teaching is step or activity that the teachers used in teaching English. Another definition, technique is a way of achieving one purpose skillfully a knack (Anthony, 2004). There are kind of techniques in teaching as follows (Keachie, 2006):

\section{A class Discussion}

A class discussion is one activity could be suitable for any class in size, even thought class discussion more effectively for small group. A discussions invited the students and learners to think critically on their subject and sometimes used logic to evaluate their position. A class discussion is really good for classroom activity to given the unit has been sufficiently covered already(Keachie, 2006).

\section{A think-pair-share}

A think pair activity is the time for learners and students for ponder the previous lesson, than discuss with one students or more of their peers, the last for share it with the class as part of formal discussion. It is during this formaldiscussion that the instructor should clarifymisconceptions. However students need a background in the subject matter to converse in ameaningful way. Therefore, a "think-pair-share" exercise is useful in situations wherelearners can identify and relate what they already know to others. So preparation is key.

A learning cell 
A learning cell is an effective way for a pair of students to study and learn together. A learning cell a process where there are two students should asking and answering questions on commonly read materials, to think and prepare for assignment, and then they write down the questions after they read. At the next class meeting, the teacher randomly puts students inpairs. The process begins by designating one student from each group to begin by asking one of their questions to the other. Once the two students discuss the question, the otherstudent ask a question and they alternate accordingly. During this time, the teacher goesfrom group to group giving feedback and answering questions. This system is also called astudent dyad.

A short written exercise

The students make a review materials and provide feedback, it is used one minute paper, however one minute paper it is does not take one minute for make summarize, but they have ten minutes to work their exercise. Teachers should employ a role-PracticeReflect approach during writing instructionand classroom activities, gradually transitioning responsibility until students are usingwriting strategies independently.

A collaborative learning group

This way good for learn in different material and different classes. This technique where teacher assign students in group three until six people and they are given an assignment or task to work together. This is good example of active learning because it causes the students to review the work that is being required at an earlier time to participant(McKinney, 2010)

A student debate

Debate make students to learn because they allow students to chance to take a position and gather information to support their view and explain it to others. These debates not only give the student a chance to participant in a fun activity but also lets them gain some experience with giving a verbal presentation(Babara, 2003)

A reaction to a video

The video help the students to understanding what they are learning at the time in presentation mode. It is also more active for the students because almost the students loved watch video or movies.

A class game 
When the students hears about the games, automatically they are very happy because it's not only help the students to review the course material before a big exam, but the games can helps them to enjoy in learning process.

From several techniques, the techniques have some roles for the teacher used in their class that make the situations in the class and students active, fun in the class, enjoyable and easier to understand the materials by use that techniques.

The Classroom activities involves interactions between the teacher and students. It means the classroom activity is some activities that the students show their educations' performance in team work or individual, if the classroom does not have real some activities, so the learning process does not effectively and the students could be a passive. Therefore, according to Masita(2017)"teacher needs to provide an authentic material andinteractive activity to engage learners' attention and createcommunicative classroomatmosphere.Moreover, teachers must dealwith time and the material stated by the curriculum.There are some examples classroom activities that can be use by schools in the classroom activities:

6. Small Groups

7. Whole class involvement

8. Reading \& Writing Exercises

In summarizing, the teacher select the most pertinent element from the material and restate them in their own words. Students also can describe the aspect of the material for the day they find most confusing. How these written exercises are used in the course will depend upon the type of class, the instructors objectives, the subject matter, and a variety of other factors. They could be collected and graded, kept in a journal(graded or ungraded), or simply used by the students themselves. From the theory above, the researcher conclude $\mathrm{s}$ many activities and the techniques the teachers used for make active and effective class. That techniques make enjoyable class, make the students feel happy they did not feel bored, and the important thing is the students easy to understood the materials by used some techniques.

According to welberg(1990) in Herna "Most of comprehensive review of effectiveness of teaching has been made by Welberg. He collected more than 3000 studies, and then carefully analyzed them to establish how important the element of effective teaching in students learning. From Welberg's result, he gather a list of weighted factors 
selected from his overall list of elements that are very related to teacher behavior in the classroom." The techniques to see the effective of effective teaching for teacher in learning process and teaching process in the classroom. The elements of effective teaching consist of academic learning time, use of positive reinforcement, cues and feedback, cooperative learning activities, classroom atmosphere, high order questioning, direct instruction, and indirect teaching.

Academic Learning Time

Academic learning time in the classroom has important variable how efficiently lesson are planned and how get started, how teachers handles discipline, digressions, off-task behavior, and the teacher handles transition will have an effect on students learning. Usually, in classroom, Indonesian's country has different rule of academic learning time each meeting has 45 minutes and the teachers in two times meeting(90 minutes).

Use of Positive Reinforcement

Based on the theory of reinforcement B.F Skinner in Hernas' Thesis reinforcement is the specialist term in operant conditioning for the stamping of stimulus associations and response habits that follows the experience of reward. Skinner's theory, as well as other reinforcement technique was later applied to classroom settings with the idea that using reinforces could increase the frequency of productive behaviors and decrease the frequency of disruptive behaviors.

There are two kinds of reinforcement; positive and negative reinforcement. Positive reinforcement is presenting a reward after a desired behavior, whereas negative reinforcement is taking away and aversive stimulus after a desired behavior.Basically, in classroom situation, positive reinforcement is when teachers praise and reward student for correct behavior. Negative reinforcement is when punishment is coupled with positive experiences for correct behavior. Studies have shown that specific praise is very effective, while general praise is hot. In other words, saying, " johnny, excellent job adding those numbers," "is much better than saying," "great job, class."

Cues and feedback

The use cues and feedback is connected for process questioning. Through cueing, the teacher provides some helps to students for answering question. While the feedback does not only correcting students, but also offering them an assessment of how well when they 
have done.(Harmer, J. 2001)Then, feedback is conceptualized information provided by an agent, such as parents, teachers, book. Regarding aspect of one's performance or understanding.(hattie, 2003)

Co-operative Learning

The effective of cooperative learning is a most interesting new finding. The main point here is the importance in the classroom of employing small-group technique with cooperative objectives. Such a procedure encourages student participation and also result in improved academic performance.

The most direct way to create classroom interaction is to adopt the principles of collaborative learning. In collaborative learning, the teacher designs a learning problem or task, and the assigns small groups of student to address the problem collaboratively. Student are typically instructed to reach a consensus on an issue, or to create a group product. The purpose of the collaborative learning is to enhance learning and achievement by encouraging peer-to-peer interaction and cooperation.(Bishop, 2000)

Classroom atmosphere

Main element of effective teaching is the need to create a relatively relaxed learning environment within teaching-learning process. The arrangement of classroom facilitation also gives an effect to the students desire to study. A positive atmosphere can make a classroom a more pleasant place to be and, in turn, a more effective, motivating place to learn. It's simple to do, and it can have positive result on the achievement of students.(Emily, 2017) Moreover, when teacher creates a positive classroom atmosphere, students learn better. Every student must feel safe and important in the class in order for maximum learning to take place. A positive classroom environment does not just happen; the teacher creates it.

Higher Order Question

A higher order question is basically a query that requires the student to analyze and produce a reasoned response, not the teacher's word. On the other hand no one an already prescribed factual answer to the question.

\section{Direct instruction}

Essentially, direct instruction is good structured. The teacher explain the lesson and material step by steps, uses advance organizers, 
checks for understanding, has students answer turn by turn in ordered style and get feedback on their answers.

Indirect Teaching

Indirect teaching there are several aspect in effectiveness teaching that is have been strongly advocated. Usually in indirect teaching including stress on independent students learning, inclusion of students ideas in discussion, and frequent students to interaction with another students.

Based on the theories above, researcher conclude that many elements of effective teaching that is very related to teacher behavior in the classroom. From the elements of effective teaching make sure the teacher can teach the students more effectively.

Vocational high school is one of the secondary educations with a specialty to prepare graduates to be ready to work. Based on (Evans in Djojonegoro, 2016) statement: "Defined that vocational school was part of educational system that prepared a person to be more capable of working at a job or a group of occupations than other fields of work." fortunately, there are integrated vocational school. Integrated vocational school is some schools includes Islamic religion in their activity, in their lesson plan. Their Islamic religion activities is really effective for students it is because the students got the knowledge about Islamic too not just about the general material.

Integrated vocational school medify and deveoped their curriculum to reach the min goals of the establishment of school is among : make the students be islamic personality, have smart think and intelegent faith(Suyanto, 2013). There are five principles that characterize the curriculumof the integrated islamic school.

- Islamic based education nd learning in all subject in the school

- Competency based learning

- Mater of Qur'an

- Know about Arabic and English language in order be able to compete in global lifes

- The actulization of student's abilities and telents

On the other hand, the purpose of integrated islamic school curriculum is not only providing knowledge and completing their vocation skill but also instiling religious values. That is why the institude said tobe 
integrated in school system, which is believed to be the foundation for forming muslim leadership.

\section{Research Methodology}

This research used qualitative methods. A qualitative case study research design was considered appropriate ininvestigating this research inquiry. The aim was to examine the teaching process in-depth and thestudents' learning activity at schools within an organizational context. The title ofthe research project indicated a qualitative research method due to its nature to explore anddiscover the factors affecting teaching effectiveness. The study investigated the view of chefinstructors teaching in culinary arts at vocational high school Islamic integrated in RejangLebong. According to Hancock "Qualitative research is concerned with developing explanation of social phenomena. It described social phenomena as they occur naturally(Bverly, 1998). This research usedthere were two instruments, the checklist observation and interview guidance. Both of instruments see the techniques and classroom activities the teachers used in the class and to see the techniques pursuant with element of effective teaching. Finally, the result of checklist observation are:

Table 1

The result of Observation the techniques teaching used by teachers

\begin{tabular}{|c|c|l|l|}
\hline \multirow{2}{*}{ No } & \multirow{2}{*}{$\begin{array}{c}\text { Teaching } \\
\text { Techniques Used } \\
\text { by Teachers }\end{array}$} & \multicolumn{2}{|c|}{ The Techniques implemented } \\
\cline { 3 - 4 } & \multirow{2}{*}{1} & SMK IT KU & \multicolumn{1}{|c|}{ SMK IT RR } \\
\hline \multirow{2}{*}{ A Class Discussion } & $\begin{array}{l}\text { The teacher A } \\
\text { splitting into } \\
\text { some groups } \\
\text { really fair. } \\
\text { The teacher invite } \\
\text { the students to } \\
\text { think critically. }\end{array}$ & $\begin{array}{l}\text { The teacher B } \\
\text { splitting into some } \\
\text { groups }\end{array}$ \\
\cline { 3 - 4 } & $\begin{array}{l}\text { The teacher mix the } \\
\text { students for make } \\
\text { good group. } \\
\text { The teacher ask the } \\
\text { students to think } \\
\text { critically. }\end{array}$ \\
\hline 2 & Think Pair Share & $\begin{array}{l}\text { The teacher A ask } \\
\text { the students }\end{array}$ & The teacher B ask \\
\hline
\end{tabular}




\begin{tabular}{|c|c|c|c|}
\hline & & $\begin{array}{l}\text { about the lesson } \\
\text { last meeting. } \\
\text { The teachers A } \\
\text { invite the student } \\
\text { who can answer } \\
\text { the question } \\
\text { about previous } \\
\text { lesson }\end{array}$ & $\begin{array}{l}\text { the students. } \\
\text { The teacher B ask } \\
\text { the students one by } \\
\text { one about previous } \\
\text { lesson } \\
\text { The teacher invite } \\
\text { the student who } \\
\text { can answer the } \\
\text { question. }\end{array}$ \\
\hline 3 & A learning Cell & $\begin{array}{l}\text { The teacher A ask } \\
\text { the students } \\
\text { sharing each } \\
\text { other about the } \\
\text { material. } \\
\text { The students must } \\
\text { prepare for the } \\
\text { assignment. }\end{array}$ & $\begin{array}{l}\text { The teacher B ask } \\
\text { the students } \\
\text { sharing }\end{array}$ \\
\hline 4 & $\begin{array}{l}\text { Short Written } \\
\text { Exercise }\end{array}$ & $\begin{array}{l}\text { The teacher A } \\
\text { instruct the } \\
\text { students to make } \\
\text { a resume after } \\
\text { learned material. } \\
\text { The students } \\
\text { received the } \\
\text { instruct from the } \\
\text { teacher. }\end{array}$ & $\begin{array}{l}\text { The teacher B } \\
\text { instruct the } \\
\text { students to make a } \\
\text { resume after } \\
\text { learned material. }\end{array}$ \\
\hline 5 & $\begin{array}{l}\text { Collaborative } \\
\text { Learning Group }\end{array}$ & $\begin{array}{l}\text { The teacher A } \\
\text { instruct the } \\
\text { students. }\end{array}$ & $\begin{array}{l}\text { The teacher B } \\
\text { become the } \\
\text { students in some } \\
\text { groups. }\end{array}$ \\
\hline 6 & Students Debate & $\begin{array}{l}\text { The teacher A give } \\
\text { big chance for the } \\
\text { students to } \\
\text { convey they idea. }\end{array}$ & - \\
\hline 7 & Reaction To A Video & $\begin{array}{l}\text { The teacher A } \\
\text { show the video or }\end{array}$ & $\begin{array}{l}\text { The teacher B show } \\
\text { the based on the }\end{array}$ \\
\hline
\end{tabular}




\begin{tabular}{|c|c|l|l|}
\hline & & movie. & $\begin{array}{l}\text { material the } \\
\text { students learn. }\end{array}$ \\
\hline 8 & Class Game & $\begin{array}{l}\text { Teacher A give the } \\
\text { students games }\end{array}$ & $\begin{array}{l}\text { the teacher B give } \\
\text { the students games }\end{array}$ \\
\hline
\end{tabular}

Based on the finding of the observations, it can be seen that the teacher almost implemented all the techniques. For the teacher $\mathrm{A}$ in integrated vocational school khoiruummah used 8 Techniques 8 techniques and the teacher B from integrated vocational school Rabbi raddiyah used 7 techniques indicators from 8 techniques

\section{Table 2}

The result of Observation the classroom activities used by teachers

\begin{tabular}{|c|c|c|c|}
\hline \multirow{2}{*}{ NO } & \multicolumn{2}{|c|}{ SMK IT KHOIRU UMMAH } & \multirow{2}{*}{$\begin{array}{c}\text { The Classroom } \\
\text { activities Used by } \\
\text { Teacher }\end{array}$} \\
\hline & Suitable techniqes & $\begin{array}{l}\text { Unsuitable } \\
\text { techniques }\end{array}$ & \\
\hline \multirow[b]{2}{*}{1} & $\begin{array}{l}\text { The teacher A } \\
\text { used classroom } \\
\text { activity pair- } \\
\text { share. }\end{array}$ & $\begin{array}{l}\text { The teacher } \\
\text { implemented } \\
\text { debate class in } \\
\text { the activities }\end{array}$ & \multirow[b]{2}{*}{ Small Group } \\
\hline & $\begin{array}{l}\text { The teacher } \\
\text { divided the } \\
\text { students in 4-5 } \\
\text { groups }\end{array}$ & & \\
\hline \multirow[b]{2}{*}{2} & $\begin{array}{l}\text { The teacher A } \\
\text { deliver a material } \\
\text { for } 15 \text { to } 20 \text {. }\end{array}$ & $\begin{array}{l}\text { The teacher used } \\
\text { the class debate }\end{array}$ & \multirow[b]{2}{*}{$\begin{array}{c}\text { Whole } \\
\text { classinvolvement }\end{array}$} \\
\hline & $\begin{array}{l}\text { The teacher } \\
\text { assigns students } \\
\text { assume the roes of }\end{array}$ & & \\
\hline
\end{tabular}




\begin{tabular}{|c|l|l|l|}
\hline & $\begin{array}{l}\text { individuals or } \\
\text { group in real } \\
\text { situation. }\end{array}$ & \\
\hline 3 & $\begin{array}{l}\text { The teachers } \\
\text { instructs students } \\
\text { to write short } \\
\text { assignment. }\end{array}$ & - & $\begin{array}{c}\text { Reading and writing } \\
\text { Exercises }\end{array}$ \\
\hline
\end{tabular}

Based on the finding of observations, it can be seen that the teacher almost implemented all classroom activities. From the table it can be seen the teacher A from KHOIRU UMMAH implemented 5 indicators in classroom activities.

\section{Table 3}

The result of Observation the classroom activities used by teacher

\begin{tabular}{|c|c|c|c|}
\hline \multirow{2}{*}{ NO } & \multicolumn{2}{|c|}{ SMK IT RABBI RADDIYAH } & \multirow{2}{*}{$\begin{array}{c}\text { The Classroom } \\
\text { activities Used by } \\
\text { Teacher }\end{array}$} \\
\hline & Suitable techniqes & $\begin{array}{l}\text { Unsuitable } \\
\text { techniques }\end{array}$ & \\
\hline 1 & $\begin{array}{l}\text { The teacher } \\
\text { divided the } \\
\text { students in } 3-5 \\
\text { groups. }\end{array}$ & $\begin{array}{l}\text { The teachers used } \\
\text { debate class for } \\
\text { ask and answer } \\
\text { each other. }\end{array}$ & Small Group \\
\hline 2 & $\begin{array}{l}\text { The teacher B } \\
\text { used class } \\
\text { discussion for } \\
\text { whole class } \\
\text { involvement. }\end{array}$ & $\begin{array}{l}\text { The teacher used } \\
\text { the class debate }\end{array}$ & $\begin{array}{c}\text { Whole } \\
\text { classinvolvement }\end{array}$ \\
\hline 3 & $\begin{array}{l}\text { The teacher } \\
\text { assigns the } \\
\text { students to write } \\
\text { some topics. } \\
\text { The teachers } \\
\text { instructs students } \\
\text { to write short } \\
\text { assignment to }\end{array}$ & - & $\begin{array}{c}\text { Reading and } \\
\text { writing Exercises }\end{array}$ \\
\hline
\end{tabular}




\begin{tabular}{|l|l|l|l|}
\hline $\begin{array}{l}\text { assess the extent } \\
\text { to which students. }\end{array}$ & & \\
\hline
\end{tabular}

Based on the finding of observations, it can be seen that the teacher almost implemented all classroom activities in classroom and the classroom activities is different with techniques but the classroom activities that reflect with technique teaching. From the table it ca be seen the teacher B in RABBY RADDIYAH implemented 4 indicators in classroom activities.

To know the classroom activities pursuant to techniques suit with the effective teaching theory, the researcher used Observation Checklist field notes. The checklist observation consist from several indicators which based on the theoryand the field notes based on 8 meetings for the teacher.The result finding of observation Checklist for the Analysis of the Techniques and classroom activities pursuant to techniques suit the effective (based on Welberg's theory) as follow:

Table 4

The result Observation Checklist for the Analysis of the Techniques and classroom activities pursuant to techniques suit the effective (based on Welberg's theory)

\begin{tabular}{|c|c|c|c|c|}
\hline \multirow{2}{*}{ NO } & \multirow{2}{*}{$\begin{array}{l}\text { Elements of } \\
\text { Effective } \\
\text { Teaching }\end{array}$} & \multirow{2}{*}{ observation } & SMK IT KU & SMK IT RR \\
\hline & & & Teacher A & Teacher B \\
\hline \multirow{3}{*}{1} & \multirow{3}{*}{$\begin{array}{c}\text { Academic } \\
\text { Learning Time }\end{array}$} & & $\begin{array}{l}\text { The teacher A } \\
\text { almost } \\
\text { manages the } \\
\text { time for } \\
\text { learning } \\
\text { activities in the } \\
\text { class }\end{array}$ & $\begin{array}{l}\text { The teacher B } \\
\text { almost } \\
\text { manages the } \\
\text { time for } \\
\text { learning } \\
\text { activities in } \\
\text { the class }\end{array}$ \\
\hline & & & $\begin{array}{l}\text { Teacher } \\
\text { manage the } \\
\text { classroom. }\end{array}$ & $\begin{array}{l}\text { Teacher } \\
\text { manage the } \\
\text { classroom. }\end{array}$ \\
\hline & & & $\begin{array}{l}\text { The teacher } \\
\text { manage the } \\
\text { time really } \\
\text { good with the }\end{array}$ & $\begin{array}{l}\text { The teacher } \\
\text { handle } \\
\text { learning time } \\
\text { focus on }\end{array}$ \\
\hline
\end{tabular}




\begin{tabular}{|c|c|c|c|c|}
\hline & & 8 & $\begin{array}{l}\text { technique } \\
\text { teaching she } \\
\text { used and } \\
\text { classroom } \\
\text { activities. } \\
\text { The teacher } \\
\text { handling the } \\
\text { students' task } \\
\text { behavior time } \\
\text { by time. } \\
\text { The teacher } \\
\text { handle learning } \\
\text { time. }\end{array}$ & $\begin{array}{l}\text { technique } \\
\text { reaction to a } \\
\text { video. }\end{array}$ \\
\hline 2 & $\begin{array}{l}\text { The Use of } \\
\text { Positive } \\
\text { Reinforcement }\end{array}$ & & $\begin{array}{l}\text { The teacher A } \\
\text { gave rewards } \\
\text { when students } \\
\text { have a good } \\
\text { score and gave } \\
\text { punishment } \\
\text { when students } \\
\text { got bad score. }\end{array}$ & $\begin{array}{l}\text { Teacher B } \\
\text { always gave } \\
\text { score for } \\
\text { students } \\
\text { because } \\
\text { students. }\end{array}$ \\
\hline 3 & $\begin{array}{l}\text { Cues and } \\
\text { Feedback }\end{array}$ & & $\begin{array}{l}\text { The teacher A } \\
\text { given the } \\
\text { students cues } \\
\text { just in CD, TPS, } \\
\text { SWE, CLGs' } \\
\text { techniques. } \\
\text { The teacher } \\
\text { give the clue for } \\
\text { answer right } \\
\text { question. }\end{array}$ & $\begin{array}{l}\text { The teacher } \\
\text { given the } \\
\text { students cues } \\
\text { just in CD, } \\
\text { TPS, SWE, } \\
\text { CLGs' } \\
\text { techniques. } \\
\text { The teacher } \\
\text { give the clue } \\
\text { for answer } \\
\text { right question. }\end{array}$ \\
\hline 4 & $\begin{array}{l}\text { Co-operative } \\
\text { Learning }\end{array}$ & & $\begin{array}{l}\text { The teacher A } \\
\text { designs a } \\
\text { learning } \\
\text { problem or } \\
\text { task and } \\
\text { further assigns }\end{array}$ & $\begin{array}{l}\text { The teacher B } \\
\text { designs a } \\
\text { learning } \\
\text { problem or } \\
\text { task and } \\
\text { further }\end{array}$ \\
\hline
\end{tabular}




\begin{tabular}{|c|c|c|c|}
\hline & & $\begin{array}{l}\text { students to } \\
\text { make some } \\
\text { small groups in } \\
\text { order to } \\
\text { address the } \\
\text { problem or } \\
\text { task } \\
\text { collaboratively } \\
\text { in elements CD, } \\
\text { LC, and CLG. }\end{array}$ & $\begin{array}{l}\text { assigns } \\
\text { students to } \\
\text { make some } \\
\text { small groups } \\
\text { in order to } \\
\text { address the } \\
\text { problem or } \\
\text { task } \\
\text { collaboratively } \\
\text { in elements } \\
\text { CD, LC, and } \\
\text { CLG. }\end{array}$ \\
\hline 5 & $\begin{array}{l}\text { Classroom } \\
\text { atmosphere }\end{array}$ & $\begin{array}{l}\text { The teacher A } \\
\text { manages the } \\
\text { classroom } \\
\text { almost all the } \\
\text { techniques. }\end{array}$ & $\begin{array}{l}\text { The teacher B } \\
\text { manages the } \\
\text { classroom } \\
\text { almost all the } \\
\text { techniques. }\end{array}$ \\
\hline 6 & $\begin{array}{l}\text { Higher Order } \\
\text { Question }\end{array}$ & $\begin{array}{l}\text { The teacher A } \\
\text { used higher } \\
\text { order question } \\
\text { in elements CD, } \\
\text { TPS, and SD. }\end{array}$ & $\begin{array}{l}\text { The teacher B } \\
\text { used higher } \\
\text { and order } \\
\text { question in } \\
\text { elements CD } \\
\text { and TPS. }\end{array}$ \\
\hline $\mathrm{b}$ & $\begin{array}{c}\text { Direct } \\
\text { Instruction }\end{array}$ & $\begin{array}{l}\text { The teacher A } \\
\text { used direct } \\
\text { instruction in } \\
\text { elements TPS, } \\
\text { LC, SWE, CLG, } \\
\text { and RV. }\end{array}$ & $\begin{array}{l}\text { The teacher B } \\
\text { used direct } \\
\text { instruction in } \\
\text { elements CD, } \\
\text { TPS, LC, SWE, } \\
\text { CLG, and RV. }\end{array}$ \\
\hline 8 & $\begin{array}{l}\text { Indirect } \\
\text { Teaching }\end{array}$ & $\begin{array}{l}\text { The teacher A } \\
\text { make the } \\
\text { students more } \\
\text { enthusiastic if } \\
\text { the teacher. } \\
\text { The teacher } \\
\text { manages the } \\
\text { learning } \\
\text { activities which } \\
\text { trigger high }\end{array}$ & $\begin{array}{l}\text { The teacher B } \\
\text { make the } \\
\text { students more } \\
\text { enthusiastic. } \\
\text { The teacher } \\
\text { manages the } \\
\text { learning } \\
\text { activities } \\
\text { which trigger } \\
\text { high }\end{array}$ \\
\hline
\end{tabular}




\begin{tabular}{|l|l|l|l|}
\hline & & frequency of & frequency of \\
& interactions & interactions \\
among students & among \\
& in class & students in \\
discussion and & class \\
collaborative & discussion and \\
& learning group & collaborative \\
& & & learning \\
& & & group. \\
\hline
\end{tabular}

Based on the result of finding observation it can be conclude there was difference among the result of the teacher A and Teacher B. From the data above, several techniques that implemented by teachers pursuant with effective teaching. The teacher A and teacher B in elements of effective teaching when they implemented the technique teaching English, that technique pursuant but Sometime teacher A and teacher B when they implemented the technique in indicators of elements effective teaching does not pursuant.

To know the classroom activities pursuant to techniques suit with the effective teaching theory. The researcher had done interview with two English teachers as the respondents. The researcher gave the questions based on the theory about the techniques the teachers used in the classroom activities. The data obtained from interview were concluded by the researcher as below:

Teacher A

From the interview with teacher $\mathrm{A}$, teacher $\mathrm{A}$ use various technique and classroom activities. The teacher apply class discussion technique and teacher A drive her students to think critically and lead her students to use their logic so that they evaluate their position in a class discussion:

"yes, of course I use the class discussions' technique. Actually in the class there are learning groups, it is finished make when the class wants to start a lesson in the early semester but every meeting the group must change the students. In every group the students must combine it is mean there are smart student, there are diligent students and there are slowly student, so they can help each other, usually to lead the students I usually show some videos to the students and play a game, because the students really like watch 
and play a game. So they can use their logic in the learning activities"

Based on the statement above, the teacher use some techniques as a indicators to make the students to think critically in the class discussion. Various techniques can make the students active.

When the researcher ask about the think air shares' techniques, the teacher use that techniques before start new material. She ask the students about the material last meeting. The teacher give a reward for the students whose can remember the material last meeting by use technique think pair share. The teacher make sure the students remember about the material last meeting before start new material. When the students sharing about the lesson each other, they will getting new information from friends, the teacher used learning cells' technique for make the students among two students sharing about the material the teacher gave. She used learning cells' technique in grade one about text recount. When the researcher ask the teacher about the short written exercise, the teacher answered as follow:

"Yes, of course every students must resume about the material they had done learn, but not all the students can convey that resume, around two or three students get a chance to convey their task to the students and teacher.

Based on the teacher answer, the researcher conclude the teacher called on the students randomly every the teacher gives the task to make sure all the students brave and accustomed for convey their opinion.

Collaborative learning group is one of the techniques the teacher A used, when the researcher ask the teacher about collaborative learning group the teacher statement is:

"Yes, in collaborative learning group there are three until five students. Every students have a job each other, before start discussion class the students choose who the leader from that group. The leader can manage the group to be a solid group, so they can do their jobs very well"

From the statement from the teacher, the researcher conclude the teacher make the students work each other in the group. The next question from the researcher is about student debate. She is the answer The statement above indicates that the teacher give task for every 
students but they learn together with the group, so their group get score until final examination.

The researcher ask about reacting a video's technique. Based on the statement, the teacher gave a treatment for the students. That treatment for make a students do not feel bored with the subject.

The last question of interview is the class games' technique the teacher used in the classroom activities. She said game is really important in learning process.The answer of the teacher can, the teacher gave the games based on the mood the students, and the students can play that games very well.

Teacher B

From the interview with teacher $\mathrm{B}$, it is found that the teacher $\mathrm{B}$ also used various kind of techniques teaching English in activities class. From the result of interview with the teacher B, she said that:

" yes, of course. I used class discussion technique when discuss about text narrative, so I give task to the students to make a group then they are I instruct to search generic structure in the text, search the characteristics, all the items about the text. Usually I force the students to write their opinion, so I know whose the students work or not usually the weakness in class discussion technique is just smart students have opinion in the group. The reason why I instruct the students to write their opinion they can get individuals' score and groups' score"

From that statement, the teacher used the class discussion technique and the teacher invite all the students to give their aspiration in the group. So, the students can get the information from the friends. When the researcher ask about the think pair share technique, the answer of the teacherthe researcher concluded the teacher is really good to used this technique, the teacher used the technique very well by her own and the teacher become the students more active. researcher about learning cell technique, the teacher said yes but seldom I used that. The teacher used learning cell technique for certain material. The answer of the teacher can be seen as follow:

"Actually I seldom used learning cell technique but when I used learning cell technique, I instruct the students to write short conversation. If the time is long I can used learning cell technique and I can test the students' speaking by tell about short conversation their had done write. 
Based on the statement above, the researcher concludes that the teacher used learning cell technique based on the material and the time, the teacher also can take students score by used learning cell technique. Used short written exercise technique is one of strategy that become the students know how to write well and how to put grammatically. From that statement from the teacher, if the teacher want to take score the students she did not used short written exercise but she instruct the students to spoken in front of their friends.

The next question is about collaborative learning group. The teacher answer she have not used collaborative learning group. Based on the teachers' statement, the researcher conclude the teacher did not used collaborative group in classroom activities.

When the researcher asked about student debate, the teacher gave the statement, the researcher concludes that she have not used the student debate technique. The researcher asked the teacher about reacting to a video. From the statement above, the teacher have not used a reaction to a video in classroom activities, the teacher instruct the students to spoken.The last question of interview is A class game technique. The statement of the teacher can concludes, the teacher gave the students games for make students more active in the classroom activities, every the students gave aspirations in the class the teacher always gave feedback for the students le a score.

\section{DISCUSSIONS}

The techniques used by teachers in teaching English in integrated vocational schools.

In this step, the researcher used checklist observation to get the result of the question about the technique used the teachers in teaching English in integrated vocational schools. The explanation is a follow:

Base on the finding of the teacher $\mathrm{A}$ and teacher $\mathrm{B}$ technique they used in classroom. Teacher A used A class discussion in active class. The teacher splitting into some groups that really fair, the students combine and sharing together, teacher B is same with teacher A, teacher B used a class discussion and make group for become the students sharing the material each other. Teacher A and teacher B in class discussion does not instruct the student to use logic to evaluate their position but both of the teachers focus on team work in the group. Next technique about think pair share, teacher A and teacher B used think pair share group technique in classroom activities, teacher $\mathrm{A}$ and teacher $\mathrm{B}$ review the 
materials last meeting before start new material but teacher $\mathrm{A}$ and teacher B invite all students to give their participations in think pair share technique.

The next technique is a learning cell, teacher A used learning cell technique and teacher B used learning cell technique sometimes, by used this technique teacher A and teacher B ask the students to work together about the materials and the students prepare for the assignment. Next short written exercise, teacher A always used this technique after learn but teacher B very seldom used this technique, teacher B instruct the students to spoken in front of friends and teacher A instruct the students to write the material based on the students' opinion. The next about collaborative learning group technique, teacher A used this technique for become the students discuss each other in the class about the material, same with teacher A teacher B used this technique but very seldom. Next, student debate technique, teacher A used this technique for make the students give their participations in the group and teacher B does not used this technique. Then, reaction to a video, teacher $A$ and teacher $B$ used video in classroom activities and the student more active in the class when the teacher used this technique. Last, class game technique, every meetings teacher A and teacher B used games in the classroom activities.

The students very interest with the material when the teacher include the game in learning process. In technique teaching the teachers $\mathrm{A}$ and $\mathrm{B}$ not implemented all the indicators of teaching technique. Teacher A just not implemented one indicator from teaching technique. The indicator from the technique is the teacher A does not ask the students to use logic to evaluate their position. There some reason why the teacher does not implemented this indicators because the teacher A became the students to evaluate their position in process of discussion. In discussion technique the teacher make sure all students gave the participant so the teacher can see the evaluate their position.

Teacher $\mathrm{B}$ does not implemented the indicators from the technique in two indicators. The indicators are the teacher does not ask the students to use logic to evaluate their position and the teacher B does not implemented student debate technique. The reason from the teacher B why dose not implemented the use logic to evaluate because the teacher B saw the evaluate from the students when the students discussion in their class. The second reason why the teacher does not implemented students debate in the learning process because the 
teacher just teach the grade one and there is no the material that support to implemented student debate.

According to HisyamZaini student debate and debate method is method that can help the students for convey their idea and opinions. There are some excess from debate method, the excess are to make the students brave to talk each other and to be responsible for the knowledge obtained in the debate process.

From the finding and the theories above, it can be said almost all the techniques of the teaching implemented by both of teachers. How ever there is one technique that one of the teacher does not implemented in learning process, the technique is student debate.

The classroom activities used by teachers in implementation techniques teaching.

Based on the finding of the teachers A and teacher B In this step, the researcher used checklist observation and notes to get the result of the question about the classroom activities used by teachers in implementation technique teaching in integrated vocational school. The explanation is a follow:

Based on the data of checklist observation and notes the researcher got in implementation classroom activities used small groups in classroom activities. There are three classroom activities in small group technique such as pair-share, buzz groups, and three steps interview. Teacher A and Teacher B used this classroom activities. Teacher A used pair-share technique by instruct the students to think what the students want to write around 30 second, one minute to make a abstract what they want to write, next the teacher gave the time 3 until 5 minutes for the students to explain the result in front of their friend in theclass. teacher A implemented this classroom activity for become the students more active in the class and the students connect each other and for classroom activities buzz groups the teacher implemented and the teacher divided the students in 4-5 students in one group. Teacher $\mathrm{A}$ does not implemented three steps interviews' classroom activities in her classroom activities because teacher A used debate class for become the students ask and answer each other.

Teacher B same with teacher A, she implemented two classroom activities in technique small group. Techer B implemented that classroom activities pair-share to became the students connect each other by discuss about the result of the students' write before that the 
teacher gave the students time to write and chose the material, and teacher B implemented buzz groups in classroom activities, teacher B divided the students in 3-5 students in one group and the teacher gave the participant in large classes. The teacher make sure the students talk about the issue, the teacher calls on some of the groups to report and ask other group to convey the conclusion by raise hands. Same with teacher A teacher B does not used three steps interview because the teacher got the information from the report of discussion in the buzz groups .

According to Jhones, there is strong empirical evidence that active involvement in the learning process in vitally important in two areas: for the mastery of the skills, such as critical thinking and problem solving that got from discussion in the group discussion.

Based on statement above the researcher concluded that the teacher A and teacher B in classroom need pair share and become the students some groups for make the students more active and the classroom activities will be good in the classroom.

From the data of checklist observation and notes the researcher got in implementation classroom activities whole class involvement. Whole class involvement there are three classroom activities. First, the teacher check, whole class debate, and role play and debates. From that classroom activities teacher A implemented all off classroom activities and teacher B does not implemented all of classroom activities in her classroom activities. teacher A deliver material to the students around 15 until 20 minutes to clearly the material next continue the next project, and the teacher A used the class debate to become the students more active to convey their opinions, the teacher A assign the students to write short assignment to assess the extent to which students understanding the material. The students make short assignment to show they understand about the material. The teacher A instruct the students to gave the arguments each other in debate, for the ending the teacher instruct the students to summary arguments for each other.

Based on the statement from Frederic, taking advantage from debate class. The advantages of the dividing aisle in large teacher halls, the instructor assigns sides of debate to the two halves of the class or by prearrangement, students sit on the side of the room representing the point of view of debate.

The researcher can conclude that the teachers used whole class involvement And students debate in classroom activities based on the 
materials, if the materials needs to use debate class the teachers used whole class involvement activities.

The data of checklist observation and notes the researcher got in implementation classroom activities Reading and writing exercise have two indicators classroom activities. First, close reading and second classroom assessment. From both of classroom activities teacher A and teacher $B$ used reading and writing exercise. Teacher A just implemented classroom assessment in her classroom activities, teacher A instruct the students to write short assignment to assess the extent to which students understanding the material. The students make short assignment to show they understand about the material. Teacher B implementation both of classroom activities, teacher B implemented close reading, teacher assigns the students to write some topics after that the students read the result of the write the topics and teacher $\mathrm{B}$ implemented classroom assessment, teachers B instructs students to write short assignment to assess the extent to which students understanding the material. The students make short assignment to show they understand about the material.

Based on the data above the researcher concludes that the teacher A and teacher B gave the students activities in the class based on the skills of the students.

The classroom activities pursuant to techniques suit the effective teaching theory.

After managing the data, the researcher found that the teacher A used all techniques teaching and teacher B used five techniques teaching English. Theresearcher got some information about it. The description about the data isdescribed as follow:

\section{Class Discussion}

The teacher apply class discussion technique and teacher A and Teacher B drive her students to think critically and lead her students to use their logic so that they evaluate their position in a class discussion, teachers said actually in the class there are learning groups, it is finished make when the class wants to start a lesson in the early semester but every meeting the group must change the students. In every group the students must combine it is mean there are smart student, there are diligent students and there are slowly student, so they can help each other, usually to lead the students the teachers usually show some videos to the students and play a game, because the students really like 
watch and play a game. So from the technique the teachers used can used can become the students used logic in the learning activities.

Based on that statement, teachers use some techniques as a indicators to make the students to think critically in the class discussion. Various techniques can make the students active. Teacher B and teacher A invite all students to give aspiration in the group become the students get information from their friends.

\section{Think Pair Share}

When the researcher ask about the think air shares' techniques, the teacher $\mathrm{A}$ and teacher $\mathrm{B}$ use that techniques before start new material. Researcher the students about the material last meeting. In the classroom before the teacher start the classroom activities in learning process the students get ice breaking from the teachers. Ice breaking like a review the material last meeting. For remember the students about the material last week the teacher gave the games and who remember the material by use game that student get reward like a score or point. From that techniques the teacher A give a reward for the students whose can remember the material last meeting apply technique think pair share. Teacher make sure the students remember about the material last meeting before start new material. Teacher $\mathrm{B}$ used this technique for make the students more active and the students implemented this technique very well, the students can remember all material start from small things until big things.

\section{Learning Cell}

When the students sharing about the lesson each other, they will getting new information from friends, the teacher A used learning cells' technique for make the students among two students sharing about the material the teacher gave. She used learning cells' technique in grade one about text recount. Teacher A really clearly implemented this technique to the students. Teacher A always instruct the students become more active in the class. That class no one student can silent, all the students talk about the topic with their partner. The teacher A used learning cells' technique for increase the students' reading ability.

\section{Short written exercise}

When the researcher ask the teacher about the short written exercise, the teacher A used this technique, but teacher B does not used this technique. Teacher A make sure every students make a resume about the material they had done learn. From that technique all the students make a resume but who 
can answer the questions from the teachers they get a chance to convey their task. That classroom activity can make the students active and want to be winner to get a score from the teacher.

Based on the teacher A answer, the researcher conclude the teacher called on the students randomly every the teacher gives the task to make sure all the students brave and accustomed for convey their opinion.

\section{Collaborative Learning Group}

Collaborative learning group is one of the techniques the teacher A used, when the researcher ask the teacher about collaborative learning group. From the statement from the teacher, the researcher conclude the teacher make the students work each other in the group. The teacher become the students in several groups, each group there are for until five students. Every groups have jobs. That technique really effective for students because the students can work together in the group and have a leader for manage every works.

\section{Student debate}

The next question from the researcher is about student debate. Teacher A used student debate technique and teacher A used student debates' technique just for several material not all material, for example talk about narrative text between first group and second group different assumption about text narrative. Every groups responsibility with their group until final examination so the score is same so the smarts' students and generals' students responsibility with their friends so they know about their job each other. From that activity the researcher indicates that the teacher give task for every students but they learn together with the group, so their group get score until final examination.

Reacting A Video

The researcher also ask about reacting a video's technique. From that technique the teacher A and B become the students spirit again in learning process. From kinds of techniques the teachers always showed the videos that have connect with the material they learn. The teacher gave a treatment for the students. That treatment for make a students do not feel bored with the subject.

\section{Class Game}

The last question of interview is the class games' technique the teacher A and teacher B used in the classroom activities. The teachers 
said game is really important in learning process. The teachers gave the games based on the mood the students, and the students can play that games very well. The teacher B become the students got score if the students gave aspiration every activities in the class. Although the game does have connecting with the material but there are dedications in that games.'

Based on the data above, the most teachers implemented all the technique of effective teaching English. From the interview, the researcher has gotten to the respondents, the researcher got the conclusion thatthe classroom activities pursuant to techniques suit the effective teaching theory, the teachers used various technique and classroom activities in the learning process in classroom such as small group, whole class involvement, and reading and writing exercise. The techniques such as a class discussion, second a think pair share, third technique a learning cell, fourth a short written exercise, fifth collaborative learning group, sixth a student debate, seventh a reaction to a video, and eighth is class game. That technique and classroom activities really help the teacher to become the students more active and that classroom activities become pursuant of elements of effective teaching.

\section{CONCLUSION}

As mentioned before, based on the finding and discussion in chapter IV can be conclude:

The first, the techniques the teachers used in teaching English at vocational high school Islamic integrated KhoiruUmmah and vocational high school Islamic integrated Rabbi Radhiyyah. Based on the result of this research the researcher concludes that the teachers have implemented all the techniques in teaching English such as a class discussion, think pair share, a learning cell short written exercise, collaborative learning group, student debate, and class game. The teachers implemented that technique in classroom activities. Every meeting the teachers change the technique for make sure the process learning of the students very well by used that techniques. Second, the classroom activities the teachers used in implementation the technique teaching already good activities in teaching English by used several activities such as small group, whole involvement, reading and writing exercise. The classroom activities reflect the technique teaching English in the classroom, every classroom activities the teachers gives the students technique and activities based on the material they learn.Last the classroom activities pursuant to techniques suit the effective teaching theory. The teachers used the techniques and the classroom activities already pursuant with the elements of effective 
teaching such as about academic learning time, the use of positive reinforcement, cues and feedback, co-operative learning, classroom atmosphere, high order question, direct Instruction, and indirect teaching. From above teacher's techniques, activities that the teachers implemented very well by follow the elements of effective teaching.

\section{SUGGESTION}

After did the observation in the classroom and interview the teachers as the respondents, the researcher would like to give some suggestions which may useful for:

\section{The schools}

The school can use the techniques and classroom activities in English class, but also the school can be use in other subject that techniques and classroom activities, it is so easy to implement in learning process in the classroom.

\section{The teachers}

Technique teaching and classroom activities is two of important keys that the teachers can use to make a good and active students in learning process the classroom. The teachers can used one or more the techniques teaching based on the theory and the teacher can pursuant the technique with elements of effective teaching based on the theory from Welbergs' to make sure the technique suit with the effective teaching. So, the teachers can used that techniques and classroom activities in the classroom.

\section{Future researcher}

The future researchers have to make the other researcher which is better than this one. The researcher hopes that the other time the other researcher investigate about how effective the technique based on the theory from Welbergs' andthis research can be used as the related finding. 


\section{REFERENCES}

Alexander,.(2015).Alexander Technique. System,31,12-15. Retract From http://www.alexandertechnique.com/, 19 May.

Apriani, E. (2017).“Utilizing Preservice English Teachers Strategies and ClassroomManagementat Junior High School in Rejang Lebong Regency." ENGLISH FRANCA: Academic Journal of English Language and Education, 1 (02), STAIN Curup. P.151

Arianie, M. (2017). "Authentic Material and Interactive Activitiesin EFL Classroom." ENGLISH FRANCA: Academic Journal of English Language and Education, 1 (02), STAIN Curup. P.115

Babara, Gross D. (2003). "Collaborative learning group and study team": San Fransisco:University of California,. P.1-2

Bishop.(2019). Classroom Interaction and Classroom Activities.http://shodhganga.inflibnet.ac.in/bitstream/10603/11241/12 /12_chapter\%204.pdf., 20 May.

Bishop, Philip.E.(2000). Classroom Interaction(Article). Valencia Community College.

Brown, H. Douglas,..(2001). Teaching by Principles: An Interactive Approach to language Pedagogy,Second Edition. New York: Addition Wesley Longman, Inc.

Chapel, Hill, CFE.(2009). Classroom activities for Activities for Active Learning. Carolina: University of North Carolina.

Chris, K.(1997). Effective Teaching in School, Theory and Practice, Nelson Thornes,. P.12-13

Consotorium, Assessment.(2019). "Classroom Activity Administration Guidelines" Retrieved from http:/sbac.portal.airast.org/wpcontent/uploads/2015/01/Alassr oomActivityAdministtrationGuidelines practiceTest1.pdf on Monday, 19 May,P.1

Diyah R, R.F. Pancaran(2013). The effect of using think-pair-share technique on the eght grade students' reading comprehension achievement at smpn 3 Bangsal Sari Jember, Vol.II, No 2, P.42

Donna Lee, F. (2017) 101 Scaffolding Techniques For Language Teaching and Learning.

Emily,L. (2017). "Create A Positive Classroom". Retrieved from http//www.wiki.com/Create-a-positive-Classroom-Atmosphere, Nov 21. 
Gusmuliana, P. (2018). "The Use of Total Physical Response Strategy at Junior HighSchool of SLBN South Curup, Rejang Lebong." ENGLISH FRANCA : Academic Journal of English Language and Education, 2,(2) IAIN Curup.

H. J., Walberg. (1990). Productive Teaching and Intruction: Assessing the Knowledge Base. Phi Delta Kappan.

Hancock, Baverly. (1998).An Introduction to Qualitative Research. Britain: Trent Focus.

Harmer, J. (2003). The Practice Of English Language Teaching. England: Longman, 2001

Hattie and Timperley, in http//rer.segepub.com.

Helen,D. (2014). Discussion as a Teaching Technique. The learning and teaching office, P.1-4.

Herna, Evita S. (2017) "The Effectiveness Of English Teaching In English Learning Process". Skripsi. Fak. Tarbiyah STAIN Curup, Curup.

Kyriacou, Chris.(2009). "Effective Teaching In school” Nelson Thornes. P.16-17.

M. user usman. Dan lilissetiawati. (1993). Upaya Optimalisasi Kegiatan Belajar Mengajar. Bandung: PT Remaja Rosadakarya.

McKeachie, W.J., Svinicki.( 2006). Teaching Tips: Strategies, Research, and Theory for College and university Teachers. Belmont, CA. Wadswort.

McKinney, Kathleen. (2010). Active Learning. Normal, IL. Center For Teaching, Learning\& Technology. The Application of Effective Teaching Theory in Higher Education. Eurasia journal.

Muhammad, N. Rahmad, S. (2016). Model of integrated Vocational School(SMK) Product in Grecik Regency".

Othman, Momala. (2017).Classroom debate as a systematic teaching/learning approach., world Applied Sciences Journal. P.15

P, Westwood. (1996). Effective Teaching.Australian Journal of Teacher Education. Flinders University.

Power, C.N.(2013).“Technical Dan Vocational Education for The TwentyFirst Century. Prospects Journal”, Vol. xxix1999, No. 1: 29-36

Satria, Exa. (2008). The Effect Of Discussion and Speech Technique Toward Student Speaking Ability.

Sudjana, Nana. (2004). Dasar-Dasar Proses Pengajaran, Jakarta: Rineka Cipta. 
180 | ENGLISH FRANCA, Vol. 3, No. 2, 2019

Stave, Graham. (2017). Teaching Secondary Students to write Effectively, Harvard University: University of California. P.19-23

Suyanto. (2018). "Sekolah Islam Terpadu: Filsafat, Ideologi, Tren Baru Pendidikan Islam di Indonesia", Vol.II2013, No. 2: 368

Vivin, Yupita S. (2016) "The Use of Learning Cell Technique to Improve students Raeding Comprehension" Skripsi. Fak. Teacher Training and Education (Salatiga : IAIN), P.10-11 